УДК 101.1:316.422.4

DOI: 10.18101/1994-0866-2020-3-61-67

\title{
К ВОПРОСУ О КРИТЕРИЯХ СОЦИАЛЬНОГО ПРОГРЕССА (КОНЦЕПЦИЯ П. А. СОРОКИНА)
}

\author{
(C) Золхоева Мария Валентиновна \\ доктор философских наук, доцент, \\ Бурятский государственный университет имени Доржи Банзарова \\ Россия, 670000, г. Улан-Удэ, ул. Смолина, 24а \\ badmaeva_maria@mail.ru
}

\begin{abstract}
Аннотация. В статье рассматриваются взгляды Питирима Сорокина, выдающегося русско-американского философа, социолога, на проблему определения сущности, особенностей и проявлений прогрессивной линии развития в социуме. Автор, опираясь на результаты обсуждения указанных вопросов философами античности, Нового времени, эпохи Просвещения, обобщая теоретические позиции, сложившиеся в западноевропейской и отечественной науке об обществе в XIX-XX вв., исследует истоки, основные этапы формирования концепции социального прогресса П. Сорокина, ее главные положения и выводы. В статье описывается эволюция представлений ученого о существовании и причинах восходящей линии развития в обществе. Как известно, в произведениях начала XX в. П. Сорокин отрицал наличие и обоснованность самой проблемы прогресса. Однако вследствие предпринятого им масштабного изучения закономерностей социокультурной динамики его позиция в корне изменилась. В работах более позднего периода Сорокин формулирует и обосновывает вывод о роли и значении неэгоистической творческой любви в качестве главного условия и критерия общественного прогресса в любой социальной системе. Ключевые слова: социальная философия; социология; общество; общественное развитие; социальный прогресс; критерии прогресса; социокультурная динамика; Питирим Сорокин; неэгоистическая творческая любовь; альтруизм.
\end{abstract}

\section{Для цитирования}

Золхоева М. В. К вопросу о критериях социального прогресса (концепция П. А. Сорокина) // Вестник Бурятского государственного университета. Философия. 2020. Вып. 3. С. 61-67.

О социальном прогрессе, его причинах, критериях, механизмах, движущих силах и т. п. веками размышляли и продолжают размышлять философы, историки, социологи, представители других отраслей социально-гуманитарного знания. Однако какой-либо общепризнанной концепции, объясняющей или описывающей прогресс, его возможность и условия, так и не сложилось. Сегодня вся палитра разнообразных мнений - от абсолютного признания прогресса в обществе до сомнений и отрицания самого явления прогрессивного движения социума - обсуждается и имеет своих приверженцев и противников.

Прогресс, как правило, представляет собой одну из форм развития, изменения состояния какого-либо целостного образования, которое характеризуется переходом от высшего к низшему, от простого к сложному, от менее совершенного к более совершенному. Прогрессивное развитие способно увеличивать самостоя- 
тельность системы, ее адаптивные возможности к среде обитания, повышать эффективность и результативность ее действий. Традиционно различают понимание прогресса и его критериев в живых и неживых системах, разумных и неразумных.

Понятие «прогресс» (от лат. progressus - движение вперед, успех) получило распространение в общественной мысли и философии эпохи Просвещения как выражение ведущих тенденций развития общества, познания и нравственности. Однако представления об определенной направленности социальных изменений зародились еще в античности. Так, по мысли Платона, общественный прогресс состоит в объединении огромной массы людей в единое совершенное государство, в переходе от уровня бытия единичного субъекта, индивида к единому государству, социальной системе, в которой каждый получает возможность максимальной и полноценной реализации своих возможностей и способностей.

Идею прогресса как движения к некоему будущему совершенству, связанному с тысячелетним Царством Христовым, в дальнейшем выдвинули христианские философы (Августин Блаженный, Фома Аквинский). В XVIII в. на основе успехов механистического естествознания выдвигается светская идея прогресса в познании (Дж. Вико, И. Гердер, И. Кант) и в общественной жизни (А. Тюрго, М. Кондорсе, Ж. Руссо). В XIX в. глубокую трактовку прогресса с позиций идеалистической диалектики дал Г. Гегель, значительный вклад сюда внесли А. СенСимон, основатель позитивизма О. Конт и его последователи. Идею прогресса взял на свое вооружение и марксизм, связав ее с проектом коммунистического переустройства общества. Мысль о безграничном коммунистическом прогрессе развивали в своих работах В. И. Ленин, его соратники и последователи. Концепция коммунистического прогресса настойчиво проповедовалась в советское время в пропаганде и общественных науках.

Между тем социальные процессы XIX и особенно XX в. показали явное несоответствие реальности разнообразным оптимистическим версиям прогресса. В конце XIX в. в западной неклассической философии (Ф. Ницше и др.) получили распространение дискуссии о «цене» прогресса, умонастроения «разочарования» в прогрессе, идеи упадка и регресса в истории, культуре, нравственности. Тенденции отказа от идеи прогресса становятся в западной науке и философии XX в. широко распространенными. Так, А. Тойнби в своей историософской теории отвергает теорию прогресса во всемирной истории. Он утверждает, что последняя не существует как целостное единство, а представляет собой истории отдельных цивилизаций, каждая из которых проходит в своем развитии определенные циклы рождение, рост, перелом, разложение, гибель. Другую аргументацию против понятия «прогресс» приводит западногерманский социолог Л. фон Визе. Он предлагает выбросить из словоупотребления само это понятие как якобы устаревшее и заменить «нейтральным» термином - «социальные изменения».

В то же время в западной социологии XIX в. в связи с бурным развитием естественных наук все большую популярность обретает позитивизм О. Конта и Г. Спенсера. В России 60-х гг. ХIX в. учение позитивизма широко пропагандировалось путем издания работ его основоположников, в частности Г. Спенсера. Особое внимание во всем мире и в России уделялось разработанной им органической теории прогресса, в которой для объяснения социальных процессов использовалось дарвиновское учение (социал-дарвинизм). 
Против позитивистской концепции прогресса в России в конце XIX начале XX в. выступил целый ряд философов и ученых: П. Л. Лавров, Н. К. Михайловский, М. М. Ковалевский и др. В частности, Н. К. Михайловский напечатал в журнале «Отечественные записки» большую статью «Что такое прогресс?», в которой затронул важнейшие вопросы, связанные с данным понятием и подверг критике спенсеровскую органическую теорию прогресса за то, что она отождествляла природу и общество и тем самым отрицала какую-либо специфику последнего. Суть своих представлений о прогрессе Михайловский выразил в предложенной им «формуле прогресса», которая хотя и содержала убедительную критику взглядов Спенсера, но сама была уязвима, поскольку не учитывала роли и значения материальных факторов в жизни общества.

В связи с рассмотрением проблемы линейных и циклических концепций исторического процесса выразил свое отношение к идеям прогресса и регресса в общественном развитии и Питирим Сорокин, который в своем понимании исторического процесса первоначально исходил из идей Е. В. де-Роберти, М. М. Ковалевского, Л. И. Петражицкого и западных теоретиков Э. Дюркгейма, Г. Спенсера, Э. Росса и др. С понятием «прогресс» Сорокин, вероятно, встретился, когда знакомился с трудами П. Л. Лаврова и Н. К. Михайловского (об этом свидетельствуют его статьи-рецензии о творчестве названных ученых). В это время у него, по всей видимости, еще не сложились собственные определенные представления о сущности прогресса. Для обстоятельного изучения этой проблемы в работе под названием «Социологический прогресс и принцип счастья», вышедшей в свет в 1912 г., Сорокин задается вопросом: можно ли считать прогрессом какой-либо из принципов «...если он прямо или косвенно ведет к уменьшению счастья и к увеличению страданий? Очевидно, нет... Всякий прогресс, ведущий к уменьшению счастья или к увеличению страдания, - не есть прогресс. Страдание никогда не было и не может быть самоцелью, а потому же не может оцениваться как нечто положительное, то есть прогрессивное. Если к этому прибавить еще то, что страдание с биологической точки зрения почти всегда является показателем разрушения организма или биологического разрушения, то социальный прогресс, при таком положении дела, становится совершенно невозможным, ибо основным условием его является прежде всего наличность биологически здоровых организмов. А здоровый организм возможен лишь при отсутствии постоянных и более или менее частых страданий; в противоположном случае организм так или иначе будет уничтожен..., а вместе с ним кончается и всякий социальный прогресс» [7, с. 510-512].

Двумя годами позже, в 1914 г., он пишет большую статью «Обзор теорий и основных проблем прогресса», в которой рассматривает соответствующие теории, созданные мыслителями различных эпох и приходит к выводу об их односторонности и даже вненаучности самой проблемы прогресса, относящейся, по его мнению, к сфере должного, а не сущего. А после анализа позитивистской концепции прогресса делает вывод, что «для этого течения было бы гораздо правильнее совсем выбросить термин "прогресс" из научного обихода и говорить только об эволюции» [2, с. 154].

Тем не менее в этом же году в монографии «Преступление и кара, подвиг и награда» на основе анализа нормативных оснований социального поведения он 
все же пытается создать некую модель прогресса, которую можно было бы описать в объективных терминах. Прогрессивным, согласно Сорокину, является то общество, в котором возрастает роль знаний, нарастает солидарность, смягчаются внешние санкции за счет усиления личной ответственности и заинтересованности в общем благе, где любовь заменяет вражду и ненависть [4, с. 352]. На наш взгляд, здесь можно увидеть истоки будущей концепции неэгоистической любви и альтруизма, которая получила развитие в позднем периоде творчества ученого, несмотря на то, что в статье «Обзор циклических концепций социально-исторического процесса», вышедшей в свет в 1927 г., Сорокин определенно и категорично заявляет: «Что касается теорий прогресса или регресса, поскольку они - «ценностные суждения» - они обречены... быть субъективными и соответственно их логической природе никогда не могут быть научными констатациями... Теории прогресса с их оценкам хорошего и плохого, прогрессивного и нет могут выражать лишь субъективные вкусы авторов и ничего больше» [7, с. 11].

В конце 30-х гг. ХХ в. Сорокин предпринимает беспрецедентное по своим масштабам исследование механизма социокультурной динамики, в котором на широчайшем эмпирическом материале обосновывает немало ценных наблюдений и выводов, касающихся закономерностей развития культуры. Это, в частности, тезис о совокупности социокультурных изменений, не означающей их механической синхронности, обоснование существования особых ритмов в жизни социума, способных как ускорить, так и, напротив, замедлить развитие социальных процессов, а также вывод о том, что достижения человеческого духа, его творческой деятельности, накапливаясь, способны оказывать благотворное воздействие на развитие всех сфер общественной жизни.

Последний тезис по сути представляет собой признание прогрессивного характера социокультурных изменений как основной тенденции в развитии социума и неэгоистической творческой любви в качестве критерия прогресса.

В дальнейших исследованиях Сорокин исследует любовь как научную проблему. Он пытается выделить четкие количественные и качественные критерии любви, ищет ее взаимосвязи и соотношения с законами энергетической динамики. С этой целью Сорокин организовал Гарвардский исследовательский центр по проблемам творческого альтруизма, сам активно участвовал в его работе, направленной на решение главной задачи - сделать человека лучше. Центр разрабатывал пути развития сострадания, симпатии, любви и соучастия во всех общественных отношениях. Программы Сорокина основывались на сравнительной, кросс-культурной перспективе, в связи с чем центр, например, проводил исследования среди менонитов и гуттеритов, которые, по мнению Сорокина, демонстрируют образцы исключительно альтруистических по своей сути сообществ.

Ученый выделяет три аспекта, три уровня любви, существенно различающиеся по своим характеристикам: космическо-онтологический, биологический и психосоциальный. В космическо-онтологическом ключе любовь наряду с истиной и красотой управляет обществом, универсумом в целом. Здесь любовь «...постигается как объединяющая, интегрирующая и гармоническая космическая сила, которая противодействует дезинтегрирующим силам хаоса, объединяет то, что разделяется враждой, строит то, что разрушается разладом, создает и поддерживает 
великий порядок во всем универсуме» [8, с. 123]. «...без функционирования биологической ипостаси любви-энергии ни сама жизнь, ни ее преемственность, ни сохранение и выживание видов, ни эволюция жизни, ни возникновение и эволюция Homo sapiens невозможны» [4, c. 262]. Наконец, на психосоциальном уровне любовь рассматривается как сочувствие, симпатия, доброта, преданность, уважение, доброжелательность (в противовес ненависти, враждебности, неприязни, зависти, антипатии). Все эти оттенки творческой неэгоистической любви проявляются как психологический опыт, внешнее поведение и социальные взаимоотношения.

По Сорокину, энергия любви оказывает создает душевный покой и благотворно влияет на продолжительность жизни: «... враждебная, раздраженная и недружелюбная эмоция лишает человека душевного спокойствия и в связи с этим (и другими путями) подрывает его здоровье и жизнеспособность. И наоборот, эмоции любви, симпатии и дружбы способствуют созиданию душевного покоя, самообладания в отношениях с окружающими и миром вообще: по этой и иным причинам такие эмоции оказывают живительный и целительный эффекты на организм при тех или иных нарушениях его деятельности» [4, с. 265].

Без сотрудничества и взаимопомощи, доброты и сердечности, гуманности и милосердия никакое сообщество не в состоянии выжить и развиваться, ибо немедленно начнет страдать от непрерывной напряженности и конфликтов.

Другими словами, энергия неэгоистической творческой любви, альтруизма, лишенного любого расчета и выгоды, становится в концепции Сорокина главным условием и критерием общественного прогресса в любой социальной системе независимо от ее уникальных особенностей и отличий.

Эти выводы и наблюдения ученого особенно актуально звучат сегодня, в XXI в., когда экологические, политические, социальные проблемы настолько остры, что для их разрешения требуются усилия каждого, всего человечества, когда мы столкнулись с крайне агрессивной атакой ранее неизвестного вируса, в короткие сроки охватившего весь мир, парализовавшего множество важнейших проектов и процессов и навсегда изменившего привычный образ жизни, когда с невероятной скоростью во всех странах растет количество инкурабельных, неизлечимых больных.

Так, установлено, что «ежегодно в мире выявляется более 10000000 новых случаев злокачественных новообразований, таким образом, ежедневно примерно 27000 пациентам ставят этот диагноз. На сегодняшний момент в мире от рака страдает более 14000000 человек, из которых 8200000 погибает... По прогнозам ВО3 (Всемирной организации здравоохранения), за 20 лет показатели смертности и заболеваемости от рака увеличатся в 2 раза: число новых случаев заболевания вырастет с 10 млн до 20 млн, а летальность с 6 млн до 12 млн» ${ }^{1}$.

В этой ситуации, на наш взгляд, Питирим Сорокин оказался абсолютно прав и проявил невероятную дальновидность и прозорливость, обосновав еще в первой половине XX в. мысль о том, что действительным критерием общественного прогресса является отнюдь не мера господства человека над миром и другими людьми,

${ }^{1}$ Российский онкологический портал [Электронный ресурc] URL: https://www. oncoforum.ru/o-rake/statistika-raka/zabolevaemost-i-smertnost-ot-raka-v-mire.html / (дата обращения: 11.11.2019). 
а подлинный гуманизм, способность и готовность каждого человека, осознавая свое единство, тождество, неразрывную взаимосвязь с другими людьми, быть готовым оказать им, близким и абсолютно незнакомым, бескорыстную помощь и поддержку, проявив, пробудив тем самым в себе свою настоящую сущность, все собственно человеческое и исполнив таким образом свое особенное предназначение.

Литература

1. Голосенко И. А. Философия истории П. Сорокина // Новая и новейшая история № 4. 1966. С. 85-93.

2. Сорокин П. Преступление и кара, подвиг и награда. СПб., 1999. 448 с.

3. Сорокин П. А. Главные тенденции нашего времени. М., 1997. 351 с.

4. Сорокин П. А. Обзор циклических концепций социально-исторического процесса // СОЦИС, 1998. № 12. С. 3-14.

5. Сорокин П. А. Социальная и культурная динамика: Исследование изменений в больших системах искусства, истины, этики, права и общественных отношений. СПб.: Изд-во РХГИ, 2000. $1056 \mathrm{c.}$

6. Сорокин П. А. Социологический прогресс и принцип счастья. Человек. Цивилизация. Общество. М., 1992. 543 с.

7. Сорокин П. А. Таинственная энергия любви // СОЦИС. 1991. № 8-9. С. 121137. $247 \mathrm{p}$.

8. Sorokin P. A. The Reconstruction Of Humanity. Boston: Beacon Press, 1948. № 8.

9. Sorokin P. A. The Ways and Power of Love. Types, Factors, and Techniques of moral Transformation. Boston: Beacon Press, 1954. 552 p.

Статья поступила в редакиию 11.09.2020; одобрена после рецензирования 25.09.2020; принята к публикаччи 28.09.2020.

\section{REVISITING THE CRITERIA OF SOCIAL PROGRESS \\ (Pitirim Sorokin's concept)}

\section{Mariya V. Zolkhoeva}

Dr. Sci. (Philos.), A/Prof.,

Dorzhi Banzarov Buryat State University

24a Smolina, Ulan-Ude 670000, Russia

badmaeva_maria@mail.ru

Abstract. The article considers the views of an outstanding Russian-American philosopher, sociologist Pitirim Sorokin on the problem of determining the character and manifestations of the progressive development of society. Relying on the results of studying these issues by the philosophers of the Antiquity, the early modern period, and the age of Enlightenment, summarizing the theoretical positions prevailing in Western European and domestic social science in the $19^{\text {th }}-20^{\text {th }}$ centuries, we have investigated the origins and the main stages of development of the concept of social progress by Pitirim Sorokin, its main provisions and conclusions. The article describes the evolution of the scientist's ideas about the reasons for existence of the ascending line of society development. As it is well known, P. Sorokin in his works of the early $20^{\text {th }}$ century denied the existence of the problem of progress itself. However, after the large-scale study of the patterns of sociocultural dynamics undertaken 
by him, the scientist had radically changed his position. In the later works P. Sorokin substantiated the significance of unselfish creative love as a main condition and criterion of social progress in any social system.

Keywords: social philosophy; sociology; society; social development; social progress; criteria of progress; socio-cultural dynamics; Pitirim Sorokin; unselfish creative love; altruism. 